\title{
Environmental Sustainability and Participatory Approaches: the Case of Italy
}

\author{
Patrizia Grifoni ${ }^{1}$, Tiziana Guzzo ${ }^{1} \&$ Fernando Ferri $^{1}$ \\ ${ }^{1}$ National Research Council, Institute for Research on Population and Social Policies, Rome, Italy \\ Correspondence: Tiziana Guzzo, National Research Council, Institute for Research on Population and Social \\ Policies, Rome, Italy. E-mail: tiziana.guzzo@irpps.cnr.it
}

Received: February 19, $2014 \quad$ Accepted: March 11, $2014 \quad$ Online Published: April 10, 2014
$\begin{aligned} & \text { doi:10.5539/jsd.v7n3p1 } \\ & \text { URL: http://dx.doi.org/10.5539/jsd.v7n3p1 }\end{aligned}$

\begin{abstract}
A big challenge of the new millennium consists of activating a large mobilization of society toward concrete, efficient and efficacy actions which promote awareness of the problems and their solutions for a sustainable environment. In order to address the different environmental issues existing today in Italy, besides correct and transparent communication, it is also needed the involvement of local communities. The greater problem is how to inform the public. Starting from an analysis of different kinds of participatory approaches, the paper proposes a classification of methods and techniques in four different typologies: participation by feedback, participation by consultation, participation by negotiating and participation by online interaction. Moreover, in depth interviews have been carried out to interdisciplinary experts to evaluate which participatory approaches are the best to use in Italy in terms of participation and cost-effectiveness, to identify constraints that limit the implementation of the different approaches and to provide solutions to overcome them.
\end{abstract}

Keywords: participatory methods, environmental sustainability, public involvement, environmental communication, policy makers, bottom-up approaches

\section{Introduction}

Governments, communities, NGOs, companies (both for production and services) are increasingly addressing problems related with environment. In particular, they accepted the challenge of mobilizing citizens and more generally society to act sustainably. In fact, the actor's involvement, such as research Institutes, local authorities, companies, businesses, investors and civil society is needed to accelerate the transition toward a sustainable society. The concept of public involvement implies the active involvement of people in planning processes, in decision-making and activities towards environmental conservation and preservation. The main objective of public involvement consists in engaging citizens by Institutions (intended as formal organizations of government and public administrations such as: municipalities, provinces, regions, State) to discuss problems and suggest alternatives or solutions in environmental issues which affect their quality of life. "Participation" "bottom-up processes" and "inclusive governance" (Few et al., 2006) allow increasing collective awareness about environmental issues, and force Institutions to incorporate greater transparency into their regulations and policies. Already in 1993, the Fifth Action Programme on the environment launched by the European Commission extended the citizens' right to be informed, toward the right to actively participate (De Marchi et al., 2001), considering public participation as the conditio sine qua non for reaching a sustainable development.

Reed (2008) classified the main historical phases of the principle of participation in environmental issues within the political agendas from sixteen to 2000:

- Sixteen: the environmental issues begin to emerge on societal and political agendas (van Tatenhove \& Leroy, 2003);

- Seventies: first experiences of direct public involvement in data collection and planning procedures (Pretty, 1995a, 1995b);

- Eighties: application of participatory approaches in local development projects, firstly in rural field and then in depressed contexts (Chambers, 1983);

- Nineties: the principle of participation for achieving a sustainable development (UNCTAD, Rio de Janeiro, 1992); 
- In 2000: disillusionment and subsequent critique of participation (Cooke \& Kothari, 2001) and finally to a growing "post-participation" consensus over best practice, learning from the mistakes and successes (Hickey \& Mohan, 2005).

Today participation is a right enshrined in International Agreements (Aarhus Convention, 1998) and in national laws (e.g. requirements for Strategic Environmental Assessment); however, there is a wide debate on the effectiveness of these approaches (Newig \& Fritsch, 2009; Irvin \& Stransbury, 2004).

The paper aims to give a contribution to the debate on how to improve the dialogue between citizens and policy-makers, starting from the well known participatory methodologies and open challenges to their implementation. Semi-standardized interviews were administrated to interdisciplinary experts in order to analyse the Italian scenario and understand which participatory approaches are the best to apply in the Italian context.

The paper is organized as follows: section 2 provides a background, section 3 introduces a description of the Italian scenario on citizen's participation and involvement; section 4 explores the main methods and techniques of participatory approaches; section 5 describes the methodological approach of the study; section 6 summarises and discusses study results; section 7 finally, concludes the paper.

\section{Background}

Public participation can be defined as "forums for exchange that are organized for the purpose of facilitating communication among government, citizens, stakeholders and interest groups, and businesses regarding a specific decision or problem" (Wittmer et al., 2006, p. 2). This is a democratic and transparent process that lead to higher compliance since citizens accept the outcomes as a product of the democratic values (Ananda \& Herath, 2003; Rauschmayer \& Risse, 2005).

The benefits of public participation in environmental policy-making are generally classified as substantive, normative and instrumental (Moynihan, 2003; Stirling, 2004, 2006; Rauschmayer \& Risse, 2005; Dietz \& Stern, 2008; Blackstock, Kelly, \& Horsey, 2007):

- Substantive: public participation by encouraging multiple perspectives lead to better solutions;

- Normative: public participation by encouraging learning, both social and individual, enriches both the individual and the society;

- Instrumental: collaborative relationships assist program implementation, diffuse conflict, increase transparency and buy-in and social trust.

The results of participation deeply depend on the used participatory methods and by other factors, such as the expertise of facilitators, the participants' level of education, their knowledge (Reed, 2008; Koonts, 2006; Richard et al., 2004). Participation can be implemented as a process of consultation, in which different levels of knowledge meet each others, but remain fundamentally separate (local know-how vs. technical knows-why) (Lundavall \& Jhonson, 2004; Renn, 2006; Reed, 2008). Participation allows citizens to build their own opinion and to criticise the information produced by the media that sometimes provide them with piecemeal information necessary to assess the social, environmental and political conditions of a country (Dispensa \& Brulle, 2003).

The community involvement is also important to select and choose relevant indicators for improving environmental monitoring and management (Frasera et al., 2006). This can provide databases that reflect local values, and on which specific management decisions can be made. Community participation for selecting relevant indicators gives some benefits (Bell \& Morse, 1999; Pretty, 1995). Firstly, indicators chosen by local input will measure what is locally important unlike those chosen by experts. Regular community input should also ensure indicators evolve over time as circumstances change (Carruthers \& Tinning, 2003) and allow projects to continue after funding stops (Freebairn \& King, 2003).

Public participation is increasingly an important and indispensable part of public policy-making. However, some weaknesses have been identified in public participation, for a lot of time and effort spent and ineffective costs without tangible benefits, for the focus on local interests, and for the difficulty to combine public and technical inputs (Ran, 2012). These limitations can be overcome by using social media that are key factors in public involvement and participation. ICT and Internet can represent an opportunity of public participation as they can take advantage by the cost reduction and facilities for access information by citizens (Kumar \& Vragov, 2009) and the reduction of time required for the participatory processes. Web technologies and social media can offer the opportunity to inform the public disseminating useful information and to stimulate public participation using the proactive behaviour which characterises social media. 
Several national and international studies are demonstrating the efficacy, the higher level of involvement and participation in communication processes on new media respect to the traditional broadcasting communication (Boyd \& Ellison, 2008; Currie, 2009a, 2009b; American Red Cross, 2011; Madden \& Zickuhr, 2011; Peng et al., 2012).

The pervasiveness of new participatory tools such as "Web 2.0 Social media", for example, Web communities, wikis and blogs, have supported the exchange of ideas and experiences among many people defining a new "architecture of participation" in the production of knowledge (Thompson, 2008). ICT tools allow promoting the careful discussion of the different values and viewpoints underlying decisions for implementing a sustainable society (Holmes \& Scoones, 2000) toward a twofold goal: to improve the quality of decisions through the inclusion of multiple perspectives, and to increase commitment towards more sustainable and effective policies.

\section{Italy: From Information to Participation}

Italy, as a member of the European Union, is working on implementing the objectives of the Kyoto Protocol and of the European Climate Action and Renewable Energy Package. Positive initiatives have been undertaken to promote energy efficiency and renewable energy. However, a good environmental education, communication and participation are necessary to improve awareness and public consciousness of environmental matters.

In Italy, several information activities related with climate change have been developed on the national level, sometimes in collaboration with international organisations. Among national initiatives, in 2005 the Ministry for Economic Development, Environment, and ISPRA - Institute for Environmental Protection and Research, carried out an information communication and education campaign on renewable energy sources, providing citizens with information on how to save energy and on how to obtain incentives for the use of renewable energies. Among international initiatives, Italy hosts the UNESCO National Week of Education for Sustainable Development every year. In 2007 the focus of the week was "Climate change" and in 2010 it was "Sustainable mobility". In 2008 the Directorate General for Communication of the European Commission carried out the survey "Europeans' attitudes towards climate change". It found that Italian people are aware of the climate change issues. $65 \%$ of the population don't think that the seriousness of climate change has been exaggerated, and 54\% think that $\mathrm{CO}_{2}$ emissions have an impact on climate change. However, there are a very high number of respondents that do not have the necessary knowledge for having an opinion; in fact $43 \%$ of them feel unable to give opinions. The survey moreover found that Italian people do not know sectors consuming most energy, and even the level of energy dependency of Italy; they have low familiarity with renewable energy sources, in particular with hydroelectric, ocean and biomass energy, while nuclear energy causes a great opposition among sources' acceptance. This lack of knowledge and awareness limits the possibility to undertake concrete actions.

Today one of the greatest challenges that Italy has to face is to improve knowledge, not only on the existing risks but in particular on new development pathways. In Italy there is a lack of national coordination of actions, as it followed EU strategy but there was not continuity in promoting national environment culture and implementing national policies and targets. Best practices are the result of local and/or individual proactiveness. The wide use of social media in the last decade is opening new perspectives in communication and participatory actions. A positive aspect is that Public Administration in Italy is approaching social media in order to address the dialogue with citizens. Pavan (2012) shows a rapid increasing trend toward it. This study found that over $30 \%$ on 247 public bodies, including all Italians regions, provinces and municipalities have an account in at least one social media like YouTube, Facebook or Twitter. The activities are mainly addressed to provide information to make transparent the decision-making processes. On the contrary, activities for consultation, collecting opinions, citizens' proposals and monitoring of choices that administration intends to accomplish, and routes of involvement, through which citizens are called to directly participate, seem quite far from being implemented.

In Italy, for achieving a sustainable development, specific actions for improving consciousness, awareness and participation are necessary. Consciousness and awareness of risks related for example to the climate change can facilitate behavioural changes both at individual and collective level. To achieve this goal it is useful to stimulate a democratic participation in decision making processes related to the improvement of life conditions. But, the question is: "which method to employ for implementing a participatory approach?"

Some studies underlined as choosing participatory method implies considering social, economic and spatial features of the involved people and their territories, such as in the study carried out by Guzzo et al. (2012) on flood risk awareness perception. The study involved some students of primary and secondary Italian schools in a participatory plan on flood risk. The study evaluated the people awareness and risk perception before and after the implemented actions. It is important to underline as the participatory approach to be chosen deeply depends by other factors connected with cultural and political issues and features of the territories of the involved people. 
To effectively engage people with environmental issues requires considering and discussing the different communication approaches, their aims, their advantages and weakness as well as an evaluation by experts about their effectiveness for the proposed matter in the Italian context.

\section{Participatory Approaches: Methods and Tools}

Participatory methods allow informing and educating the public, exchanging information and opinions, discussing issues and processes. The implementation of these methods can be very useful to promote the transition towards shared sustainable development models based on a great careful use of resources.

Starting from an analysis of different kinds of participatory approaches, we propose a classification of methods and techniques in four different typologies: Participation by feedback (Public hearings, Public surveys, Focus Groups); Participation by consultation (European Awareness Scenario Workshop, Revision Citizen Committees, Referendums); Participation by negotiating (negotiating of rules); Participation by online interaction (ICT tools: social networks, virtual communities, blogs, forums) (See Table 1).

Table 1. Classification of participatory approaches

\begin{tabular}{|c|c|c|}
\hline $\begin{array}{c}\text { KIND OF } \\
\text { PARTICIPATION }\end{array}$ & AIMS & $\begin{array}{l}\text { METHODS AND } \\
\text { TECHNIQUES }\end{array}$ \\
\hline $\begin{array}{l}\text { Participation by } \\
\text { feedback }\end{array}$ & $\begin{array}{l}\text { Inform and educate } \\
\text { the public, ask for } \\
\text { their opinions }\end{array}$ & $\begin{array}{l}\text { Public hearing; Public surveys } \\
\text { (interviews, questionnaires); Focus } \\
\text { groups }\end{array}$ \\
\hline $\begin{array}{l}\text { Participation by } \\
\text { consultation }\end{array}$ & $\begin{array}{l}\text { Supply as well as } \\
\text { acquire knowledge }\end{array}$ & $\begin{array}{l}\text { European Awareness Scenario } \\
\text { Workshop- EASW; Revision } \\
\text { Citizen Committee; Referendum }\end{array}$ \\
\hline $\begin{array}{l}\text { Participation by } \\
\text { negotiating }\end{array}$ & Reduce conflict & Mediation rules \\
\hline $\begin{array}{l}\text { Participation by } \\
\text { online interaction }\end{array}$ & $\begin{array}{l}\text { Peer-to-peer learning } \\
\text { by knowledge sharing }\end{array}$ & $\begin{array}{l}\text { ICT tools Web } 2.0 / 3.0 \\
\text { (social networks, forum, blogs) }\end{array}$ \\
\hline
\end{tabular}

\subsection{Participation by Feedback}

This approach is based on an active role of citizens, aiming to inform and educate the public as well as ask for their opinions. It is used for improving citizens' awareness, for engaging discussions about best practices to adopt and for allowing experts to show people how to modify their life styles and respect the natural environment. Discussions among experts, stakeholders, local representatives, associations and citizens can be also encouraged through thematic events, conferences and seminars planned to develop public debates. Exhibitions and scientific workshops can be designed for allowing school groups to learn about environmental topics and for encouraging policy makers to act according to best practices.

The methods most frequently used are:

- Public hearings. They aim to illustrate the topic, to provide a common knowledge and look for the individual and community involvement. The benefit is to reach a large number of people. The disadvantage is that not all people can express their own opinion.

- Public surveys (e.g. interviews, questionnaires). They provide a representative view of public opinion without the presentation in public. The main advantage consists of the possibility to receive a lot of opinions and anonymity that enables to eliminate probable inhibition caused by speaking in public. The limit is that it does not allow for answers ad personam.

- Focus Groups. They allow collecting opinions and attitudes, to build excitement from spontaneous combination of participants' comments and to provide an opportunity to learn more about a topic or issue. The advantage consists in being able to act on small groups. The limit is the poor social representation of the involved groups.

This approach can be useful in the initial phase of participation process in order to give information to people and obtain their feedback and their beliefs. 


\subsection{Participation by Consultation}

This approach aims to supply and acquire knowledge. It is used by decision makers to look for advices, information and opinions about strategies, policies and services. It aims to consult and communicate with citizens and stakeholders in order to understand the needs and to work towards a common outcome. Citizens are encouraged to be involved by decision makers to facilitate a best accepted outcome about issues that affect their lives. Participants are invited to play an active role in generating ideas starting from which a comprehensive set of options can be developed as well as decisions can be taken together with public administrators.

The most frequently used methods are:

- European Awareness Scenario Workshop (EASW). Participants meet each other to exchange points of view, develop visions for the future of their community and propose ways to overcome the obstacles that hinder the transition towards sustainable development models. The advantage of using these methodologies is the high degree of formalization of the process corresponding to a high degree of legitimacy of the same. The limit is that politicians do not always accept the conclusions of the workshop and do not implement actions to reach results.

- Revision Citizen Committees. They allow an inexpert public to participate in decisions that affect complex issues such as the environment. In general, committees work side by side with local authorities, providing them with social support in the decisions. The main advantages are: the access to technical information and the ability to discuss evidence and issues. The disadvantage is that the acceptance of citizen's presence limits the political freedom of choice of administrators.

- Referendums. They give citizens the opportunity to vote issues for approval. The advantages are that they are a snapshot of public opinion in a given moment; they do not allow compromise between groups. The limit is that a low voter turnout determines that results may be not representative. This process is very costly.

This approach is fundamental for the participation democratic process. It emphasises an equality value in that all citizens have a right to express themselves with their ideas and opinions.

\subsection{Participation by Negotiating}

This approach aims to reduce conflicts and to achieve a compromise. In the negotiation process there is a participation of the interest group representatives, but not the wide participation of population. Negotiation consists of a dialogue between two or more people or parties. It is intended to reach an understanding, resolve points of difference produce an agreement upon courses of action, negotiate for obtaining advantage, satisfying different interests of involved parties in negotiation process.

The method most frequently used is:

- Mediation rules. It is useful as a means to resolve conflicts related to political and technical choices. The advantage is the acceptance of preventive rules. The limits are: withdrawal of the delegation or excessive time in the process leading to a loss of interest and legitimacy.

\subsection{Participation by Online Interaction}

This approach aims to peer-to-peer learn by knowledge sharing. It allows a large involvement of citizens to enhance their consciousness and participation by using social media and viral communication, exchanging and sharing ideas and experiences through networks of relationships. These new participatory tools, such as Web 2.0, provide important opportunities and challenges to complex concerns such as environmental issues because they allow informing and raising awareness at all level of society.

This approach requires using:

- ICT tools (social networks, virtual communities, blogs, forums). They enable people to share knowledge and opinions, to discuss about issues, to provide a space for uploading links and documents, to post messages and make questions. The most important advantages consist of a greater information exchange, knowledge sharing and increased transparency. The biggest limit is the digital divide, in fact not all people has a connection to the Internet and is able to use it.

This approach can be considered transversal to the previous approaches because methods and techniques before described can be facilitated by the use of online tools. 


\section{Methodology}

The main objective of the study addressed in this paper is to understand how participatory approaches are used in Italy, identifying advantages and weakness on their implementation and how it is possible to overcome constraints that hinder its full development. In order to find a strategy to enhance the networking, dialogue and interchange among multiple stakeholders (researchers, national Institutions, society, non-profit organizations and media) interdisciplinary experts have been involved in a qualitative study. A semi-structured interview guide was defined with the objectives: (1) to understand if participatory approaches have been used in Italy to enhance environmental awareness of people; (2) to identify the best ways to involve public by using these approaches, (3) to identify efficacy, and cost-effectiveness of each proposed approach (classified in the previous section), (4) to identify constraints that limit the implementation of the different approaches, (5) to provide solutions to overcome them.

These objectives were addressed by the following guiding questions:

- Which is the situation in Italy with respect to the participation of citizens in environmental issues?

- Are participatory approaches used to enhance people awareness towards these themes?

- If yes, with what results? If not, why?

- Could they be used for this purpose?

- With what advantages and limits?

- How could limits be overcome?

- Which participatory approaches are most suitable to achieve the low carbon society? Why?

- Can you identify the goodness degree of proposed methods and techniques in terms of participation, outcomes and costs?

- How is it possible to improve the link between communication and participation to involve people?

- Which are constraints that limit the application of participatory approaches?

- How these constraints could be overcome?

Fifteen experts were selected, (six women and nine men, aged from forty to sixty-five years old), according to their knowledge on environment and participatory approaches. In particular interviewed were researchers (representing different disciplines: sociology, communication, natural science, engineering) from National Research Council (CNR) and Italian National Agency for New Technologies, Energy and Sustainable Economic Development (ENEA) with experience in participatory methodologies sustainable development and Information Communication Technologies. Local authorities from the province of Rome and Lazio region working on climate change and environmental sustainability. A briefing-paper in advance encouraged individual preparation. Each participant was given information on key issues and guiding questions. As the interviews were open, interviewed had the possibility to expand or add other comments to the asked question. The average time of individual interviews was an hour and a half. The interviews proceeded from September until December 2012. By interviewing experts with different backgrounds, a diversified set of opinions on the issue was collected. After collection data were organized in the following macro-areas a) the situation in Italy, b) evaluation of the participatory approaches and c) constraints to implement them. Then these opinions were analysed and summarised and some integrals phrases of experts were reported in the paper, to better understand the different viewpoint.

\section{Results: The Point of View of the Experts}

In the following sections there is an analysis of experts opinion according to i) the situation in Italy about the environmental sustainability and their challenges, ii) an evaluation of the participatory approaches according to their effectiveness in terms of participation, outcomes and costs and iii) an analysis of the constraints to implement them.

\subsection{The Situation in Italy}

According to the expert's opinion, the issue of environmental sustainability is poorly addressed in Italy both at the citizen's level and at the technical and political level. In particular, bottom-up participation actions (involving citizens) have not yet been completely implemented, they still are in a preliminary stage. In fact, this subject is not sufficiently considered in the information agenda. One of the experts interviewed said: "The theme of increasing awareness on environmental issues is not a priority of the policy agenda of Italy. We have a kind of 
policy reactive and non-active. In fact, implemented policies mainly react to disasters, but they do not address preventing them. This approach doesn't allow citizens' involvement".

Experts claimed that participatory approaches require an information and communication common background that is still quite insufficient in Italy, as underlined by the interview that follows: "In some activities that we held in Italy mainly on desertification and application of thermonuclear fusion for example, we preferred to firstly do activities of public hearings in order to explain to people the topic subject of the discussion, using other participatory approaches only in a second time".

According to the experts, there are several participatory activities that seek to reduce the emission of carbon dioxide and they are generally preceded by information actions. This is the only way to get citizens' awareness and involvement. One of the most used participatory systems in Italy in the environment and energy field is the referendum, a form of direct participation that does not affect the status quo. "By the referendum, in Italy you can decide to abolish a law; for example in the two referendums on nuclear energy production, there was not a proposal for doing something, but they aimed to stop any initiative of production of energy using nuclear power plant". In italian history referendum has only been used to abrogate a rule (i.e. it doesn't get something in exchange for something else, but it only abrogates a rule).

To increase public awareness towards these issues, citizens need to share information and knowledge. An expert claimed that it is necessary to make a distinction between information and communication. In the information process there is not feedback, and information only is conveyed. In the communication process, beyond giving information people is able to respond playing an active role. The challenge we have to face in order to ensure citizens participation consists in stimulating, not only the implementation of an information process, but also a real communication process involving experts, Institutions and the public, as expressed by one of the experts' opinion: "I think we should work on policy, assuming the need for a holistic approach to environmental problems. This approach intends that the environmental and energy policies are included in those of development".

The lack of communication and participation caused different problems also in economic terms. For example, technological actions for the building of plants, perceived by people as dangerous, created several conflicts in Italy and consequently delays both in terms of time and economic loss.

According to interviewed experts, in order to improve communication and participation and involve more and more people there are two possible ways. One based on long paths, like the interest in the environment and science created in schools with the aim of building future responsible citizens. The second way adopts a communication strategy mainly based on emergency, in which communication is made for particular events such as earthquakes, floods, etc. "The two approaches cannot be alternatives; they should be opportunely combined to reach the best solution".

\subsection{Evaluation of Participatory Methods}

Experts during their interviews evaluated the participatory methods and techniques according to their effectiveness in terms of participation, outcomes and costs. They used a ranking of colors to indicate the goodness of the different methods, as follows: Invalid = red; Partially valid = orange; Valid = yellow; Excellent $=$ green $($ See Tables 2-3-4).

Table 2. Goodness degree of proposed methods and techniques in terms of participation

\begin{tabular}{|c|c|c|c|}
\hline OBJECTIVE & INDICATOR & $\begin{array}{l}\text { PARTICIPATORY } \\
\text { METHODS }\end{array}$ & $\begin{array}{l}\text { VALIDITY OF } \\
\text { THE METHODS }\end{array}$ \\
\hline \multirow{8}{*}{$\begin{array}{l}\text { Effectiveness of } \\
\text { involvement in } \\
\text { terms of } \\
\text { participation }\end{array}$} & \multirow{8}{*}{$\begin{array}{l}\text { Quantity of } \\
\text { information and } \\
\text { data provided } \\
\text { and acquired } \\
\text { from people }\end{array}$} & Public hearings & Valid \\
\hline & & Public surveys & Invalid \\
\hline & & Focus groups & Valid \\
\hline & & $\begin{array}{c}\text { European Awareness Scenario } \\
\text { Workshop - EASW }\end{array}$ & Excellent \\
\hline & & Citizens review committees & Invalid \\
\hline & & Performances and exhibitions & Invalid \\
\hline & & Mediation rules & Invalid \\
\hline & & ICT and web systems & Partially valid \\
\hline
\end{tabular}


Table 3. Goodness degree of proposed methods and techniques in terms of outcomes

\begin{tabular}{|c|c|c|c|}
\hline OBJECTIVE & INDICATOR & $\begin{array}{c}\text { PARTICIPATORY } \\
\text { METHODS }\end{array}$ & $\begin{array}{c}\text { VALIDITY OF } \\
\text { THE METHODS }\end{array}$ \\
\hline $\begin{array}{c}\text { Involvement of } \\
\text { citizens in } \\
\text { terms of } \\
\text { outcomes }\end{array}$ & $\begin{array}{c}\text { Increase of } \\
\text { involvement of } \\
\text { citizens }\end{array}$ & Public hearings & Partially valid \\
\cline { 3 - 4 } & & Public surveys & Invalid \\
\cline { 3 - 4 } & & Focus groups & Valid \\
\cline { 3 - 4 } & & $\begin{array}{c}\text { Europcan Awarcness Sccnario } \\
\text { Workshop - EASW }\end{array}$ & Exccllent \\
\cline { 3 - 4 } & Citizens review committees & Invalid \\
\cline { 3 - 4 } & & Performances and exhibitions & Invalid \\
\cline { 3 - 4 } & Mediation rules & Invalid \\
\cline { 3 - 4 } & & ICT and web systems & Partially valid \\
\hline
\end{tabular}

Table 4. Goodness degree of proposed methods and techniques in terms of costs

\begin{tabular}{|c|c|c|c|}
\hline OBJECTIVE & INDICATOR & $\begin{array}{c}\text { PARTICIPATORY } \\
\text { METHODS }\end{array}$ & $\begin{array}{c}\text { VALIDITY OF } \\
\text { THE METHODS }\end{array}$ \\
\hline Involvement of & & Reduced costs \\
citizens in & and times & Public hearings & Excellent \\
\cline { 3 - 3 } terms of costs & & Public surveys & Invalid \\
\cline { 3 - 4 } & & Focus groups & Partially valid \\
\cline { 3 - 4 } & & $\begin{array}{c}\text { Europcan Awarcness Scenario } \\
\text { Workshop - EASW }\end{array}$ & Excellent \\
\cline { 3 - 4 } & & Citizens review committees & Invalid \\
\cline { 3 - 4 } & & Performances and exhibitions & Invalid \\
\cline { 3 - 4 } & & Mediation rules & Invalid \\
\cline { 3 - 4 } & & ICT and web systems & Excellent \\
\hline
\end{tabular}

The motivations of the results of the experts' evaluation, for each method, are given below:

- Public hearings are effective in terms of participation, they are good methods for providing common information to people, however they do not bring immediate results. They are effective in terms of costs, because require reduced times (usually two hours are required).

- Public surveys are tools that allow acquiring information and data from people, checking the situation of their information and awareness level; they also allow having short discussion with people. However public surveys are not valid from the standpoint of participation, because questionnaires or interviews do not enable people to participate. By using these methods, people typically cannot express themselves. Moreover, they are not effective in terms of cost because they are very expensive.

- Focus groups consist in an experiment with two groups, in which information is given only to one group and not the other. This method is used primarily to evaluate the weight of given information. It is a valid method both in terms of participation and results. In term of costs, it is partially valid, because it is not a cheap method.

- $\quad E A S W$ is a method of participation, in which future scenarios are presented, and thus the citizens must already know what we are talking about. This method is excellent in terms of participation as it is repeatable also because it is not expensive.

- Citizens review committees are not very good participatory methods, because usually people are chosen by local administration and it is not so good in terms of participation.

- Mediation rules are not a system suited in Italy. Mediation is done for large countries where there are independent authorities that form the mediator. In Italy there is not an independent authority. The Canadian and Anglo-Saxon mediation is made for simple laws, not for complex laws, (the Italian code includes 22,000 between environmental norms and laws). Unlike if we have a bureaucratic structure so that it is difficult to find rules for building a solid base for the mediation. The Italian legal system is convoluted, complex and is not suited for mediation rules.

- $\quad$ ICT and Web systems are partially valid in terms of participation, as they can be very effective because enable an interactive participation among people, experts and Institutions increasing the participatory democracy. Furthermore, they are excellent in terms of costs and times, because using them it is possible reach people around the world easily and repeatedly. 


\subsection{Constraints to Implement Participatory Approaches}

According to the experts, to implement effectively participatory approaches, it is needed to overcome the existing barriers for their use in decision-making processes and practice (as political, cultural, historical, social, institutional/legal, economic sectors). In many cases the scientific outcomes remain rooted solely within the scientific community or new knowledge is not presented in a way to be implemented by stakeholders and end-users. In other cases the approaches are also tailored solely to single cases and it is not clear how they might be modified to address problems of a complex and integrated character (e.g. von Elverfeldt \& Glade, 2005).

Experts cited some constraints that limit the application of participatory methods, among these:

- High investment in time, training and funds. Financial resources and time for training in these methods are required and for selecting, introducing and adapting suitable methods. Participatory processes need also funds in order to involve larger groups with different perceptions and interests.

- Social, educational and cultural differences. Participatory methods and tools have to be adapted to the specific social and cultural contexts of participants. Communication during public presentations has to be arranged according to different literacy of people, so they can build trust and they can feel free enough to speak about their concerns and opinions.

- Participatory manipulation. There is the risk that groups with best communication skills and higher social status can dominate weaker ones. This can lead to a manipulation process.

- Acceptance of participatory approaches by citizens. It is difficult to demonstrate to people the qualitative and quantitative evidence of impact of participatory approaches, due mainly to mistrust towards Institution by citizens. Furthermore in hierarchical and centralized Institutions there is the fear to lose control over a process.

- Poor knowledge and understanding of the issues. Documents are longs, complex, too technical and difficult for public understanding. Accessibility by all people is difficult due to the lack of understanding and knowledge of such approaches.

- Different characteristics of involved actors. It is needed to improve collaboration and role played by different actors (e. g. public sectors, citizens, private sectors) considering their characteristics and interactions. Citizens are not a homogenous group: for example older people have to be addressed in another way than younger people.

- Confidence-Trust. Inadequate information about environmental issues, opaque procedures and lack of public participation in decision-making lead to severe criticism and distrust of decisions. These problems contribute to a lack of trust in policy.

Experts provided different solutions to overcome these limits for the implementation of participatory approaches. According to the experts, the first thing to do is to change behaviours towards environment. The green economy is particularly suitable because it does not act on emergencies but on everyday lifestyles and eco-friendly behaviours. This requires long life learning; the understanding of scientific phenomena should become an education topic in schools. It is necessary to spread the culture of the environment and energy, creating a culture of science and improving the cultural level at least to a minimum level of understanding shared. Furthermore, during the participatory approaches, communicators should use an understandable language for all targets involved. There is the need to improve information and communication and provide citizens with tools that help them to understand and to improve their trust. It can be improved by information and knowledge sharing, and improving the citizen's capability in reasoning that reduces the risk of manipulation. In some cases, the participants of a participatory action are chosen by a mayor, but no one should impose that choice. Information and knowledge have to be widely shared. Experts individuated this possibility in information technologies. The pervasiveness of new participatory tools, in fact, such as Web 2.0 tools, Web community, wikis and blogs, have changed the way people access information and exchange ideas and experiences. The interactive environment in social media extends the traditional one-way media communication model to a two-way communication model in the public domain. Viral communication furthermore, allows transferring information with a low effort and low cost, from small to very large-scale diffusion, implementing the participation and involvement "paradigm".

\section{Discussion and Conclusion}

The paper analysed participatory approaches for citizens' involvement in environmental issues, discussing the Italian scenario. Interviewed experts individuated some methods and techniques considered most effective for 
people participation in the Italian context. In particular, the best methods indicated were: EASW, public hearings and focus groups because they are most effective at local level, and ICT tools for their pervasiveness.

Experts proposed an integration of methods and tools in order to improve the dialogue between citizens and stakeholders. In particular, at a first step they suggested using the public hearings, because they can give first information about issues and make citizens most aware about the discussed problems. At a second step, they suggested using EASW as a concrete and excellent method in terms of participation, results and costs. Another valid method that can be used is focus group. It has been considered as a valid method both in terms of participation and results, but not in terms of costs.

Experts, in order to improve the dialogue between citizens and stakeholders, recommend some actions to do. In particular, some of them suggested acting on the Institutions that are closer to citizens at local level. Other experts, instead, suggested modifying people behaviours mainly acting in schools, creating interest in environmental issues. In their opinion, it is also necessary to increase the Italian politicians' awareness on the importance to implement bottom-up and not top-down participatory approaches in decision making processes. In order to address the different environmental issues existing today in Italy, besides correct and transparent communication, it is also needed the involvement of local communities. It is very difficult for Institutions, to produce information, communicate it in order to converge towards dialectical processes without undermining the pluralism of actors, interests and ideas. There are indeed two types of communication: one aimed at persuading people that is fundamentally manipulative, and one that tends to provide information so that people can form an opinion. A democratic communication must be open and bi-directional between expert and public and it should facilitate the ability and willingness of the citizens to assess the information. The difference between the two forms is subtle and is more a matter of intents than of contents, but involves different routes: a technocratic path the first, and democratic the second. The first objective of a communication should be to provide the tools, resources and knowledge to discern between being informed and educated and being handled and trained. Information and education enable a conscious participation that puts people in a position to make decisions based on what they know their values and needs.

In Italy there is a large demand from citizens for their direct involvement in public decision-making, particularly in the field of environmental management policies and of technologies. There is a need of strong policy actions, and the transformation from a "reactive" to an "active" policy, that acts not only during an emergency but also assumes the precautionary principle, informing and involving people. This can be possible thanks to the new online participatory tools. They, in fact, provide important opportunities and challenges to complex concerns such as environmental issues because they allow to inform and raise awareness at all level of society supporting building of coalitions and, in particular, they carry peer-to-peer learning. They enable citizens and experts to share data and information and to participate in all places and at any time through the lifecycle of policy development and implementation. This has the potential to make the decision making process more democratic and at the same time it increases the level of trust and likelihood of acceptance and successful implementation. There is the need to integrate different on-line and off-line methods and techniques to involve citizens in a democratic process, not only with information activities but also and mainly with consultation activities.

A future challenge in Italy is to overcome issues like accessibility, the costs of equipment and telephone connections, computer illiteracy and to implement effective participation on these emerging online tools that could have several positive effects both on transparency and involvement processes. E-government in all countries is going in this direction with the aim to promote an inclusive information society.

\section{References}

American Red Cross. (2011). Social Media in Disasters and Emergencies. Retrieved from http://www.redcross.org/www-files/Documents/pdf/SocialMediainDisasters.pdf

Ananda, J., \& Herath, G. (2003). Incorporating stakeholder values into regional forest planning: A value function approach. Ecological Economics, 45, 75-90. http://dx.doi.org/10.1016/S0921-8009(03)00004-1

Bell, S., \& Morse, S. (1999). Sustainability indicators. In S. Bell \& S. Morse (Eds.), Measuring the Immeasurable. London: Earthscan Publications Ltd.

Blackstock, K. L., Kelly, G. J., \& Horsey, B. L. (2007). Developing and applying a framework to evaluate participatory research for sustainability. Ecological Economics, 60, $726-742$. http://dx.doi.org/10.1016/j.ecolecon.2006.05.014

Boyd, D. M., \& Ellison, N. B. (2008). Social network sites: Definition, history, and scholarship. Journal of Computer-Mediated Communication, 13, 210-230. http://dx.doi.org/10.1111/j.1083-6101.2007.00393.x 
Carruthers, G., \& Tinning, G. (2003). Where, and how, do monitoring and sustainability indicators fit into environmental management systems? Australian Journal of Experimental Agriculture, 43, 307-323. http://dx.doi.org/10.1071/EA00177

Chambers, R. (1983). Rural Development: Putting the Last First. Longman, Harlow.

Cooke, B., \& Kothari, U. (2001). Participation: the New Tyranny. London: Zed Books.

Currie, D. (2009a). Expert round table on social media and risk communication during times of crisis: Strategic challenges and opportunities. Retrieved http:/www.apha.org/NR/rdonlyres/4791OBED-3371-46B3-85 C2-67EFB80D88F8/0/socialmedreport.pdf

Currie, D. (2009b). Public health leaders using social media to convey emergencies. Nation's Health, 39(6), 1-30.

De Marchi, B., Funtowicz, S., \& Pereira, Â. G. (2001). From the right to be informed to the right to participate: Responding to the evolution of the European legislation with ICT. International Journal of Environment and Pollution, 15(1), 1-21. http://dx.doi.org/10.1504/IJEP.2001.000588

Dietz, T., \& Stern, P. C. (2008). Public participation in environmental assessment and decision making. Washington. D. C.: National Academies Press.

Directorate General for Communication of the European Commission. (2008). Europeans' attitudes towards climate change. Special Eurobaromenter 300. Retrieved from http://ec.europa.eu/public_opinion/archives/ebs/ebs_300_full_en.pdf

Dispensa, J. M., \& Brulle, R. J. (2003). Media's social construction of environmental issues: focus on global warming - a comparative study. International Journal of Sociology and Social Policy, 23(10), 74-105. http://dx.doi.org/10.1108/01443330310790327

European Commission. (1998). Aarhus Convention on access to information, public participation in decision making and access to justice in environmental matters. 25 June 1998. EU Document No. ECE/CEP/43.

Few, R., Brown, K., \& Tompkins, E. L. (2006). Working paper 95: Public participation and climate change adaptation. Tyndall Centre for Climate Change Research: Norwich, UK.

Frasera, E. D. G., Dougilla, A. J., Mabeeb, W. E., Reeda, M., \& Alpinec, P. M. (2006). Bottom up and top down: Analysis of participatory processes for sustainability indicator identification as a pathway to community empowerment and sustainable environmental management. Journal of Environmental Management, 78, 114-127. http://dx.doi.org/10.1016/j.jenvman.2005.04.009

Freebairn, D. M., \& King, C. A. (2003). Reflections on collectively working toward sustainability: indicators for indicators! Australian Journal of Experimental Agriculture, 43, 223-238. http://dx.doi.org/10.1071/EA00195

Green, A. J. (1997). Public participation and environmental policy outcomes. Canadian Public Policy, 23(4), 435-458. http://dx.doi.org/10.2307/3552073

Guzzo, T., Ferri, F., Grifoni, P., \& Firus, K. (2012). Flood Risk Awareness: An Experiment Using School Students to Inform Families and Friends. International Journal of Risk and Contingency Management (IJRCM), 1(1), 49-63. http://dx.doi.org/10.4018/ijrcm.2012010104

Hickey, S., \& Mohan, G. (2005). Participation: from tyranny to transformation? Exploring new approaches to participation in development. Zed Books.

Holmes, T., \& Scoones, I. (2000). Participatory environmental policy processes: Experiences from North and South. WP 113 (Institute of Development Studies, Brighton, Sussex).

Irvin, R. A., \& Stansbury, J. (2004). Citizen participation in decision making: is it worth the effort? Public Administration Review, 64(1), 55-65. http://dx.doi.org/10.1111/j.1540-6210.2004.00346.x

Koontz, T. M., \& Thomas, C. W. (2006). What do we know and need to know about the environmental outcomes of collaborative management? Public Administration Review, 66(s1). http://dx.doi.org/10.1111/j.1540-6210.2006.00671.x

Kumar, N., \& Vragov, R. (2009). Active Citizen Participation Using ICT Tools. Communications of the ACM, 52(1), 118-121. http://dx.doi.org/10.1145/1435417.1435444

Lundvall, B., \& Johnson, B. (1994). The Learning Economy. Journal of Industry Studies, 1(2), 23-42. http://dx.doi.org/10.1080/13662719400000002 
Madden, M., \& Zickuhr, K. (2011). 65\% of online adults use social networking sites. Retrieved August 26, 2011, from http://pewinternet.org/Reports/2011/SocialNetworkingites/Overview.aspx

Moynihan, D. P. (2003). Normative and instrumental perspectives on public participation. American Review of Public Administration, 33(2), 164-188. http://dx.doi.org/10.1177/0275074003251379

Newig, J., \& Fritsch, O. (2009). Environmental governance: participatory, multi-level - and effective? Environmental Policy and Governance, 19(3), 197-214. http://dx.doi.org/10.1002/eet.509

Pavan, F. (2012). Dossier: I social media nella Pubblica Amministrazione. Retrieved from http://datastorage02.maggioli.it/data/docs/www.egov.maggioli.it/Francesco_Pavan_dossier_i_social_media _nella_Pubblica_Amministrazione.pdf

Peng, T., Zhang, L., Zhong, Z., \& Zhu, J. J. H. (2012). Mapping the landscape of Internet studies: Text mining of social science journal articles 2000-2009. Working paper.

Pretty, J. N. (1995a). Participatory learning for sustainable agriculture. World Development, 23, $1247-1263$. http://dx.doi.org/10.1016/0305-750X(95)00046-F

Pretty, J. N. (1995b). A trainer's guide for participatory learning and action. International Institute for Environment and Development.

Ran, B. (2012). Evaluating Public Participation in Environmental Policy-Making. Journal of US-China Public Administration, 9(4), 407-423.

Rauschmayer, F., \& Risse, N. (2005). A framework for the selection of participatory approaches for SEA. Environmental Impact Assessment Review, 25, 650-666. http://dx.doi.org/10.1016/j.eiar.2004.09.005

Reed, M. S. (2008). Stakeholder Participation for Environmental Management: A literature Review. Biological Conservation, 141, 2417-2431. http://dx.doi.org/10.1016/j.biocon.2008.07.014

Renn, O. (2006). Participatory process for designing environmental policies. Land Use Policy, $23,34-43$. http://dx.doi.org/10.1016/j.landusepol.2004.08.005

Richards, C., Blackstock, K. L., \& Carter, C. E. (2004). Practical Approaches to Participation SERG Policy Brief No.1. Macauley Land Use Research Institute, Aberdeen.

Stirling, A. (2004). Opening up or closing down: Analysis, participation and power in the social appraisal of technology. In M. Leach, I. Scoones, \& B. Wynne (Eds.), Science, Citizenship and Globalisation (pp. 218-231). London: Zed.

Stirling, A. (2006). Analysis, participation and power: Justification and closure in participatory multi-criteria analysis. Land Use Policy, 23(1), 95-107. http://dx.doi.org/10.1016/j.landusepol.2004.08.010

Thompson, M. (2008). ICT and development studies: Towards development 2.0. Journal of International Development, 20, 821-835. http://dx.doi.org/10.1002/jid.1498

van Tatenhove, J. P. M., \& Leroy, P. (2003). Environment and participation in a context of political modernisation. Environmental Values, 12, 155-174. http://dx.doi.org/10.3197/096327103129341270

von Elverfeldt, K., \& Glade, T. (2005). MultiRISK - An innovative conceptual approach to model natural risks. Geophysical Research Abstracts, 7, 06758.

Wittmer, H., Rauschmayer, F., \& Klauer, B. (2006). How to select instruments for the resolution of environmental conflicts? Land Use Policy, 23, 1-9. http://dx.doi.org/10.1016/j.landusepol.2004.09.003

\section{Copyrights}

Copyright for this article is retained by the author(s), with first publication rights granted to the journal.

This is an open-access article distributed under the terms and conditions of the Creative Commons Attribution license (http://creativecommons.org/licenses/by/3.0/). 